\title{
視覚的作業支援情報の操作対象物に対する追従呈示の効果の検討 1
}

\author{
藤原悠史 ${ }^{2}$, 篠原一光 ${ }^{2}$, 北村昭彦 2 , 佐々木 誠 $^{3}$
}

\begin{abstract}
This study investigated the effect of visual support information which tracks an operational object on task performance and workload. In the experiment, participants answered the number of the same objects on screen that is presented as visual support information. There were three conditions for presentation of visual support information; tracking condition in which support information tracked the motion of a mouse cursor on a screen, back monitor condition in which support information was presented on the right monitor of the screen, near monitor condition in which support information was presented on a monitor which is in front of participants. Participant's fatigue was measured with flicker test and "Jikaku-shou sirabe", and mental workload was measured with the Japanese version of NASA Task Load Index (NASA-TLX). Results showed that reaction time was the shortest under tracking condition when the largest number of object was presented on the screen. Mental workload was the lowest under tracking condition. Therefore tracking presentation of visual support information facilitated the task performance and decreased mental workload.
\end{abstract}

本研究では，視覚的作業支援情報の操作対象物に対する追従呈示が作業パフォーマンスと作業負担に 及ぼす影響について検討した。作業支援情報として呈示した罒形と同じ図形がスクリーン上に何個呈示 されているのかをキー押しで回答する課題をおこなった．作業支援情報の呈示方法は，スクリーン上に 呈示されたマウスカーソルを追従する条件とスクリーン横のモニタに呈示される条件と実験参加者の近 くのモニタに呈示される条件の3条件であった. 実験参加者の疲労はフリッカーテストと自覚症しらべ, 精神的負担は日本語版NASA-TLXによって測定した．結果，スクリーン上に一度に呈示される図形の数 が最も多い時に追従条件で反応時間が最も短くなった。また，追従呈示した場合に主観的な精神的負担 は最も低く評価された．したがって，追従呈示では作業効率が良くなり，主観的な精神的負担が軽減さ れることが示された。

(キーワード：作業支援情報，追従，精神的負担，ヘッドアップ・ディスプレイ，視覚的負荷）

\section{1.はじめに}

近年，建設分野では情報化施工がおこなわれている. 情報化施工とは，建設生産プロセスの施工段階において ICTを用いることで得られた電子情報を活用することで ある1). そうした情報化施工の中のひとつに，作業支援 情報の利用がある. 例えば，ショベルカーでの掘削作業 の場合, 前方の地形情報や掘削の深さなどを示す作業支 援情報がモニタ上に表示される.オペレータはその作業 支援情報を確認しながら重機を操作することで，作業を

1 受付：2018年7月2日 受理 : 2019年3月31日

2 大阪大学大学院人間科学研究科

Osaka University, Graduate School of Human Sciences

3 株式会社コマツ

Komatsu. Ltd.
効率的におこなうことができる，その一方で，オペレー タは作業中に何度も前方の地形とモニタに表示された作 業支援情報の間で視線を移動させる必要があるため，視 覚的負荷が高くなる．情報取得に要する視覚的負荷が高 い場合，作業パフォーマンスが低下することが示されて いる2 5). 作業の効率や安全性を高めるためにも，作業 支援情報の呈示位置や呈示方法を検討する必要があり， その解決策のひとつとしてへッドアップ・ディスプレイ (Head up Display；HUD）の利用が期待されている.

情報を前方風景に重畳呈示するHUDでは，情報が利用 者の視野内に呈示されることで, 情報確認時に生じる視 線移動量が少なくなり ${ }^{6)}$, 視覚的負荷が軽減される。そ の結果，HUD利用時は作業パフォーマンスが向上した

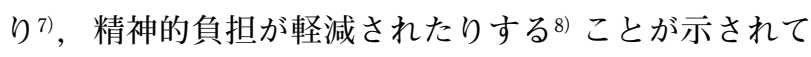
いる.

HUDの多くは航空機や自動車に搭載されているが, 
HUDを導入した建設機械の開発も進められている ${ }^{9)}$. た だし，現時点で実用化されているHUDのコンバイナは小 さいため，前方の一部分にしか情報を表示することがで きない. しかし，技術が発展することで，将来的には作 業支援情報を前方のさまざまな位置に呈示することが可 能になると期待されている10).

作業支援情報の呈示方法として，操作対象物に追従す るような情報呈示方法が有効であると期待される. 例えば, ショベルカーで掘削作業をおこなう時に, 操作対象物で あるバケット (ショベル) の動きを作業支援情報が追従 し，常に操作対象物の隣に呈示されるという方法が考え られる。それにより，一般的なHUDのように前方の一部 に情報が固定呈示される場合に比べて，情報を確認する 際に生じる視線移動量が軽減され，視覚的負荷が小さく なると考えられる.したがって, 追従呈示した場合, 建 機オペレータの作業パフォーマンスが更に高くなり, 負 担も軽減されると予想される. しかし，建機オペレータ の視界前面の広範囲に情報を投影するようなHUDがまだ 実用化されていないこともあり，追従呈示の効果につい てはこれまで検討されていない.

自動車用HUDではフロントガラス全面をHUDとして利 用できる技術が開発されているが，建設機械でも同様に， オペレータの視界の広い範囲に人工的な映像を投影する 技術が今後開発されることが十分に予想される. その際 にどのような視覚情報の呈示方法が望ましいかを検討し ておくことは人間工学的に意義があると考える. そこで 本研究では，視覚的作業支援情報が操作対象物を追従す る場合の作業パフォーマンスとオペレータの疲労や負担 について検討した. なお, 本研究では追従呈示の効果の 検討に焦点を当てたため, HUDは用いない実験となって いる.

\section{2. 方 法}

\section{2-1. 実験参加者}

実験参加者は18名（男性13名，女性5名）で，平均年 歯令は25.06歳（標準偏差2.60）であった。全員が裸眼また は矯正で正常な視力（0.7以上）を有していた.

\section{2-2. 実験装置}

実験装置の配置を図1に示した。実験参加者の正面奥 側にスクリーン $(1200 \mathrm{~mm} \times 900 \mathrm{~mm})$ ，その右隣にモニタ (奥モニタ：LG 42LA6600-JA， $376.3 \mathrm{~mm} \times 301.1 \mathrm{~mm}$ ) を 設置した。 また，実験参加者の右手前にもモニタ（手前
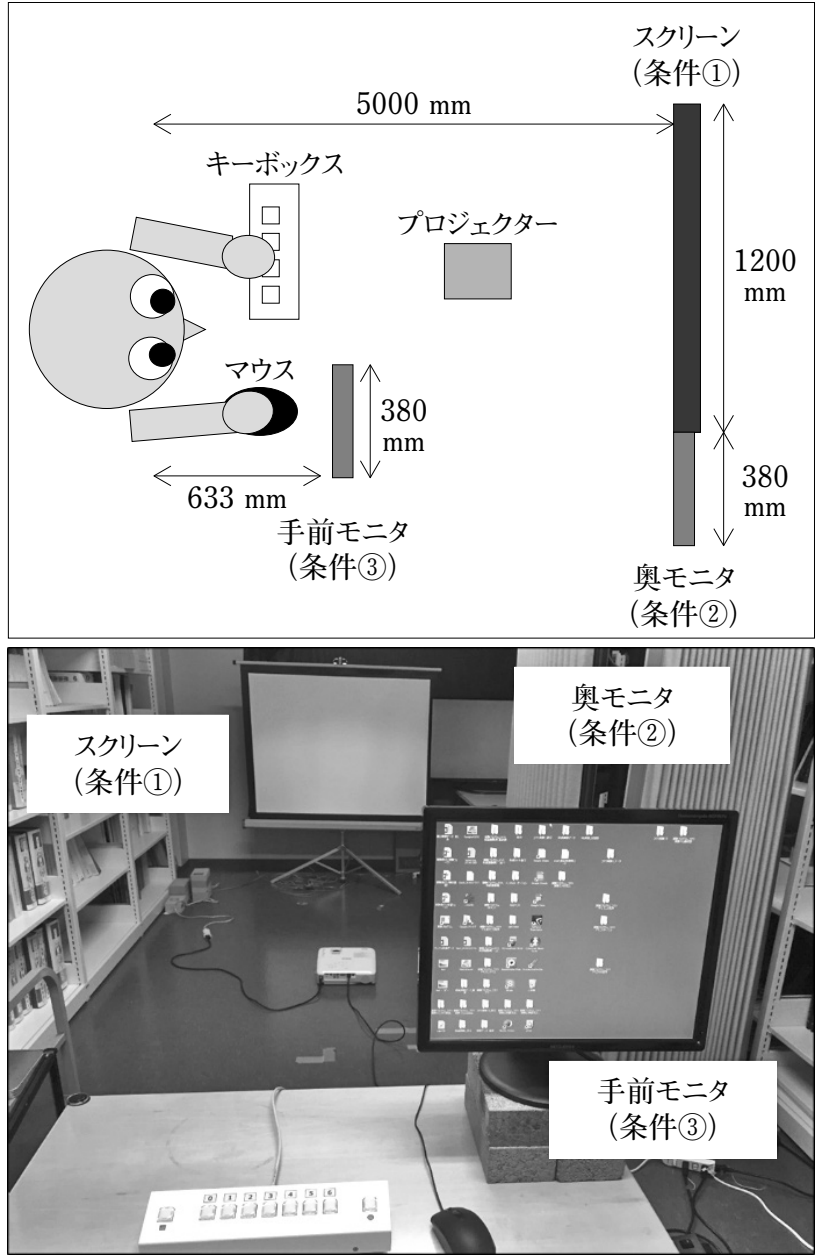

図1 実験装置の配置図（上）と写真（下）

Fig. 1 The arrangement of the experimental apparatus.

モニタ : MITSUBISHI RDT197V， $376.3 \mathrm{~mm} \times 301.1 \mathrm{~mm}$ ) を設置した。 プロジェクタはEPSON製EB-S31であり， スクリーン全面に映像を投影した。実験参加者からスク リーンと奥モニタまでの距離は $5000 \mathrm{~mm}$ ，手前モニタま での距離は633 mmであった. スクリーンと奥モニタと手

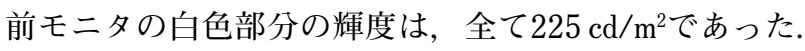
また，実験は暗室でおこなった。

\section{2-3. 測定指標}

本実験では，作業パフォーマンスの指標として課題に おける反応時間を用いた。

主観的な精神的負担の指標として, 日本語版NASA$\mathrm{TLX}^{11)}$ から算出した適応加重平均ワークロード得点 (AWWL得点) と下位項目（知的知覚的要求，身体的要 求, タイムプレッシャー, 作業成績, フラストレーション, 努力）の得点を用いた ${ }^{12)}$.

実験参加者の疲労の客観的な指標として，フリッカー 值測定器II型（竹井機器工業株式会社製 T.K.K.501C）に 
よって測定したフリッカーテストの值（フリッカー值） を用いた。 また，疲労の主観的な指標として，日本産 業衛生学会・産業疲労研究会の作成した「自覚症しら べ」13)の得点を用いた，自覚症しらべは5群（ねむけ感， 不安定感，不快感，だるさ感，ぼやけ感）にカテゴリー 化された 25 項目から構成された質問紙であり，各群の平 均得点を算出した.

\section{2-4. 手続き}

実験では，正面奥のスクリーン上に10個の立方体から 構成された立体図形が複数呈示された（図2）。また，視 覚的な作業支援情報として1個の立体図形がスクリーン 上あるいはモニタ上に呈示された。実験参加者は作業支 援情報と同じ立体図形（以降ターゲットと表記する）が スクリーン上に何個あるのかを可能な限り早くキー押し で回答した。建設機械での作業では作業支援情報の確認 を繰り返しおこなうため，その作業を模したものとして このような実験課題を用いた。課題中に同一の立体図形 が異なる回転角度で呈示されることはなかった.

作業支援情報の呈示方法は3つの条件があった。 (1)追 従条件では，作業支援情報がスクリーン上のマウスのポ インタの右下に透過率50\%で呈示され, 実験参加者の操 作するマウスのポインタの動きを追従した (図2)。これは, ショベルカーのように建設機械の一部を操作して作業す る場合に，HUDに表示した作業支援情報が操作対象物の 動きを追従し，常に隣に呈示される状況を模擬した条件 であった，(2)奥モニタ条件では，奥モニタ上に作業支援 情報が呈示された（3)手前モニタ条件では，手前モニタ 上に作業支援情報が呈示された，奥モ二タ条件と手前モ ニタ条件では作業支援情報はポインタを追従せず，常に 同一の位置に呈示された．実験は呈示条件ごとにブロッ クに分けて打こなった。ブロックの実施順序は，実験参 加者間でカウンターバランスをとった，スクリーンと手 前モニタと奥モニタに呈示した画像の中心は，実験参加 者の体の中心から視角にしてそれぞれ左に $4.58^{\circ}$ ，右に $6.87^{\circ}$ ，右に $6.87^{\circ}$ であった。手前モニタと奥モニタは実 験参加者から見て一直線上に設置しており，奥モニタ条 件では手前モニタを取り除いて実験を実施した。また， 実験中は椅子に座って課題をおこなった。

ターゲットの数は，0〜4個の間でランダムであった. 一度にスクリーン上に呈示される図形の数（以降七ット サイズと表記する) は，7個と9個と11個の3水準を設け た。スクリーン上の図形の配置パターンは90種類あり, ターゲットの個数とセットサイズは試行ごとにランダム な順序で呈示した。ターゲット 0 4個の試行の呈示確率

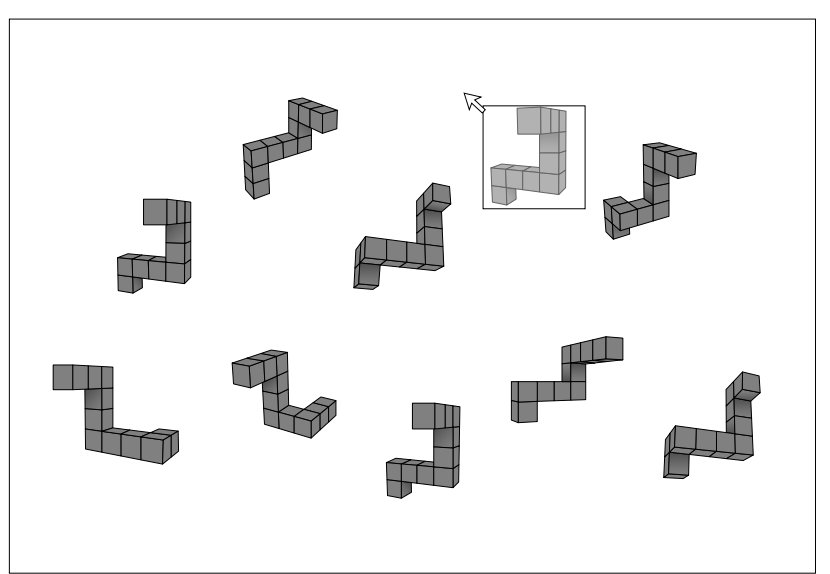

図2 スクリーン上に呈示された実験刺激の例（図は追従条 件での呈示例を示す．奥モニタ条件と手前モニタ条件で は作業支援情報はモニタ上に呈示された.）

Fig. 2 The example of the experimental stimulus on screen. (Fig. 2 shows the example of tracking condition. Visual support information is displayed on a monitor in back monitor condition and near monitor condition.)

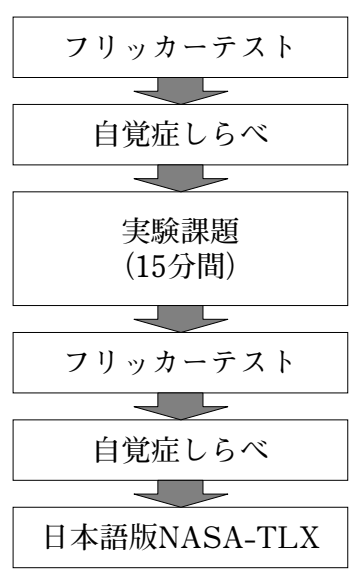

図3各ブロックの実験の流れ

Fig. 3 Experimental procedure on each condition.

は各 $20 \%$ あ゙った。

各ブロックの実験の流れを図3に示した。各ブロック の課題終了後に，主観的な精神的負担を測定するために 日本語版NASA-TLXに回答するように求めた。 また，各 ブロックの課題前後に, 疲労を計測するためにフリッカー テストを実施し，自覚症しらべに回答するように求めた.

本実験は，大阪大学大学院人間科学研究科研究倫理委 員会の審查と承諾を得て打こなった。承認番号は人行 29-034であった．実験前には書面によるインフォームド コンセントを取得した。実験終了後，実験参加者には謝 礼として1425円を後日支払った.

\section{2-5. 実験計画}

実験条件（3水準：追従，奥モニタ，手前モニタ）×セッ 
トサイズ（3水準：7個，9個，11個）の参加者内2要因計 画であった。本実験では実験条件の違いが疲労や精神的 負担に及ぼす影響を調べるために，各ブロックの課題時 間を15分に統一し，時間が来るまでは何度でも試行を 繰り返した。よって，各ブロックの試行数は一定ではな かった.

\section{3. 結 果}

\section{3-1. 反応時間}

各条件の平均反応時間を図4に示した，反応時間が 平均 $\pm 3 \mathrm{SD}$ 以上のデータは外机值として 80 個のデータ と，誤答の試行の496個のデータを分析対象から除外し， 3132個のデータを分析対象とした，正答率は，セットサ イズ7個の時に追従条件 $95 \%$, 奥モニタ条件 $92 \%$ ，手前 モニタ条件 $92 \%$ ，七ットサイズ 9 個の時に追従条件 $91 \%$, 奥モニタ条件 $92 \%$, 手前モニタ条件 $90 \%$, セットサイズ 11 個の時に追従条件 $90 \%$, 奥モニタ条件 $90 \%$, 手前モニ

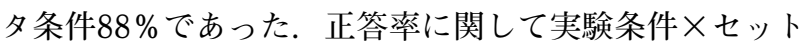
サイズの参加者内 2 要因分散分析をおこなった結果，い ずれの要因に扔いても主効果はみられず，交互作用もみ られなかった（それぞれ $F(2 ， 34)=0.18 ，$ n.s.,$\eta_{\mathrm{p}}{ }^{2}=.01$ ； $F(2,34)=0.83$, n.s., $\eta_{\mathrm{p}}{ }^{2}=.05 ; F(4,68)=0.83$, n.s., $\left.\eta_{\mathrm{p}}{ }^{2}=.05\right)$.

反応時間に関して実験条件メセットサイズの参加者内 2 要因分散分析を抢こなった結果, 実験条件とセットサイズ の主効果がそれぞれ有意であった（それぞれ $F(2 ， 34)=$ $5.36, p<.05, \eta_{\mathrm{p}}{ }^{2}=.26 ; F(2,34)=215.33, p<.01$,

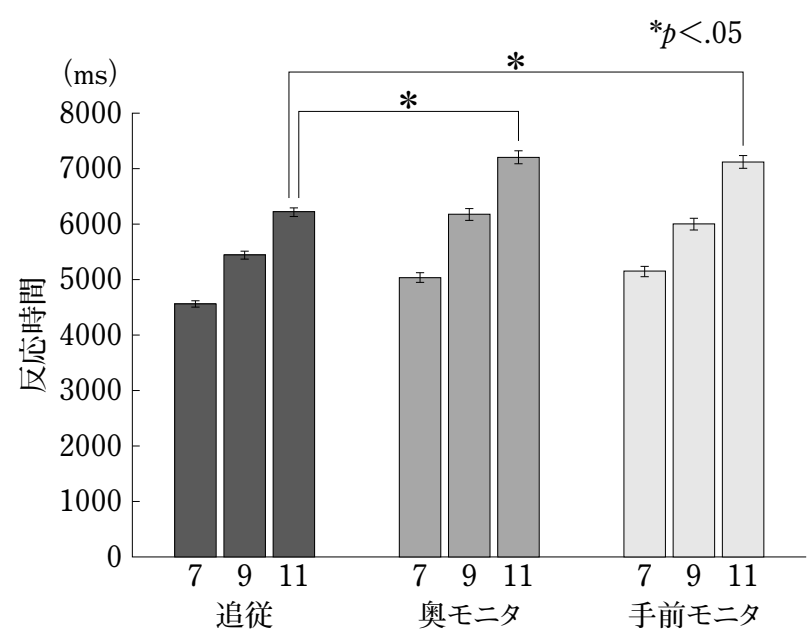

図4 各条件の平均反応時間 (エラーバーは標準誤差)

Fig. 4 Reaction time on each condition. Error bar indicates standard error. $\left.\eta_{\mathrm{p}}{ }^{2}=.93\right)$. さらに, 実験条件とセットサイズの交互作用 が有意であった $\left(F(4,68)=5.34, p<.01, \eta_{\mathrm{p}}{ }^{2}=.26\right)$.

各セットサイズにおける実験条件の単純主効果の検定 を抢こなった結果，七ットサイズが11個の時に実験条件 の単純主効果がみられた $\left(F(2,34)=8.42, p<.01, \eta_{\mathrm{p}}{ }^{2}\right.$ =.36). Shaffer法による多重比較をおこなったところ, 追従条件が奥モニタ条件と手前モニタ条件よりも反応時 間が短くなることが示された（それぞれ $p<.05, d=.39)$. また，各実験条件におけるセットサイ ズの単純主効果の検定を打こなった結果，すべての実験 条件においてセットサイズの単純主効果がみられた（追 従 $F(2,34)=111.55, p<.01, \eta_{\mathrm{p}}{ }^{2}=.88$; 奥モニタ $F(2$, $34)=148.19, p<.01, \eta_{p}{ }^{2}=.91$; 手前モニタ $F(2,34)=$ $\left.116.18, p<.01, \eta_{\mathrm{p}}{ }^{2}=.89\right)$. 多重比較をおこなったところ, 追従条件ではセットサイズ7個と9個，7個と11個，9個と 11個の間でそれぞれ有意な差がみられた（それぞれ $<.01 ，$ $d=.53 ; p<.01, d=.97 ; p<.01, d=.42)$. 奥乇ニ夕条 件に打いても，七ットサイズ間でそれぞれ有意差がみら れた（それぞれ $p<.01 ， d=.50 ; p<.01 ， d=.95 ; p<.01 ，$ $d=.41)$. 手前モニタ条件に打いても，七ットサイズ間 でそれぞれ有意差がみられた（それぞれ $<.01 ， d=.38$ ； $p<.01, d=.83 ; p<.01, d=.45)$. したがって，いずれ の実験条件においても，七ットサイズが大きくなるにつ れて反応時間が長くなった。

\section{3-2. 主観的な精神的負担}

各条件に打ける平均AWWL得点を図5に示した。実験 条件に関して参加者内1要因分散分析を打こなった結果, 実験条件の効果がみられた $(F(2,34)=10.57, p<.01$, $\left.\eta_{\mathrm{p}}{ }^{2}=.41\right)$. Shaffer法による多重比較を打こなった結果, 追従条件は奥モニタ条件と手前モニタ条件よりも平均

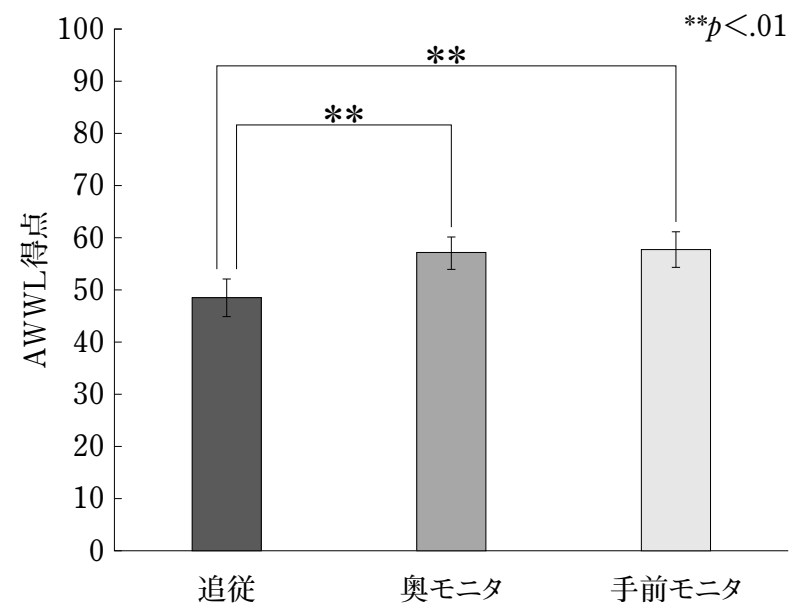

図5 各条件における平均AWWL得点

Fig. 5 AWWL score on each condition. 

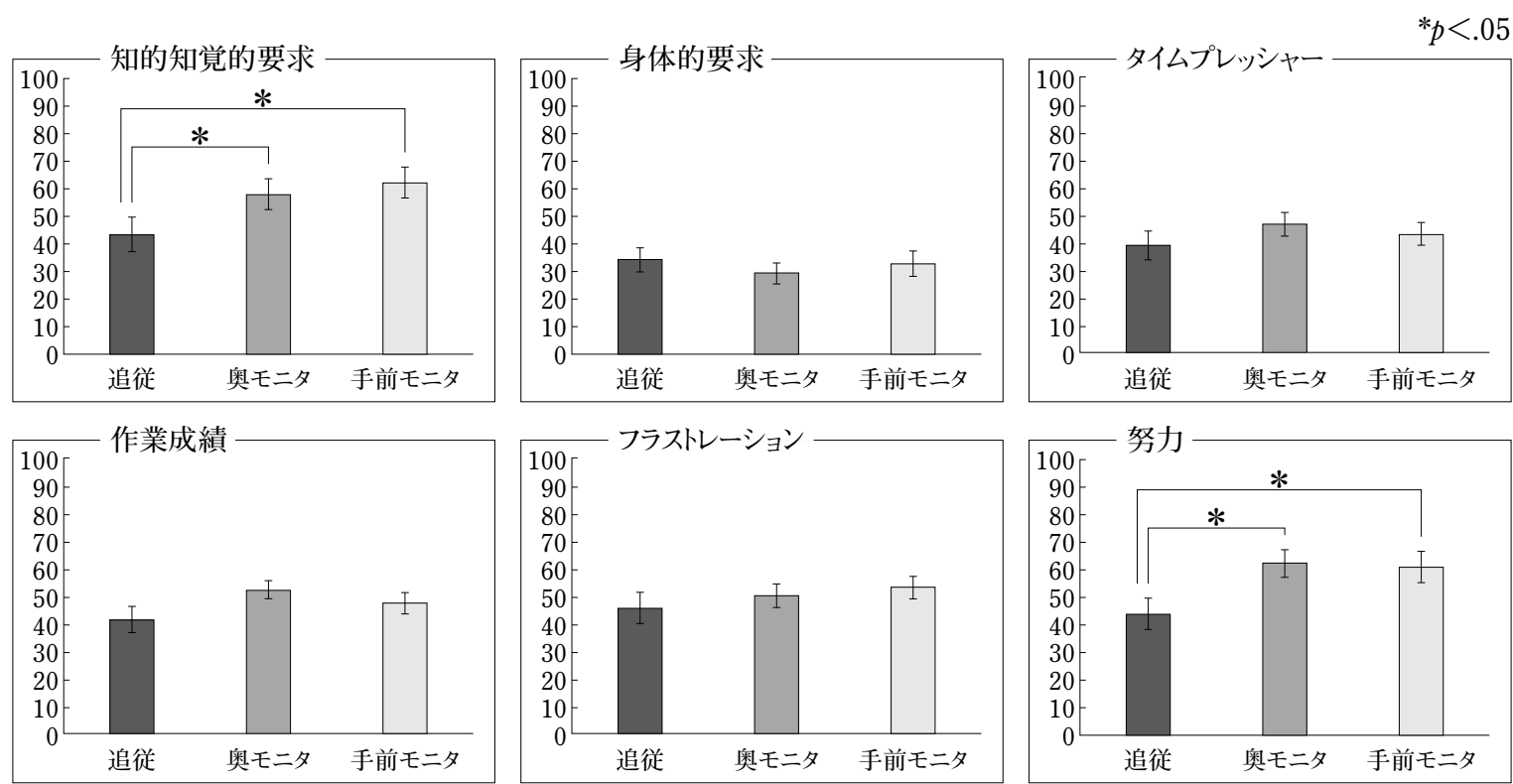

図6 日本語版NASA-TLXの下位項目における各条件の平均得点

Fig. 6 NASA-TLX ratings on each condition.

表1 自覚症しらべの得点の分散分析結果

Tab. 1 Analysis of variance (ANOVA) results of "Jikaku-shou sirabe" scores.

\begin{tabular}{lccccccccc}
\hline & \multicolumn{3}{c}{} & 実験条件 & \multicolumn{3}{c}{ 課題前後 } & \multicolumn{3}{c}{ 実験条件 ×課題前後 } \\
\hline & $F$ 值 & $p$ 值 & $\eta_{\mathrm{p}}{ }^{2}$ & $F$ 值 & $p$ 值 & $\eta_{\mathrm{p}}{ }^{2}$ & $F$ 值 & $p$ 值 & $\eta_{\mathrm{p}}{ }^{2}$ \\
\hline ねむけ感 & 1.74 & .19 & .10 & 5.57 & .03 & .27 & .62 & .55 & .04 \\
不安定感 & 2.37 & .11 & .13 & .18 & .68 & .01 & .60 & .55 & .04 \\
不快感 & 1.35 & .28 & .08 & 11.21 & .01 & .43 & .91 & .41 & .06 \\
だるさ感 & 1.04 & .37 & .06 & 4.60 & .05 & .23 & .39 & .68 & .03 \\
ぼやけ感 & .81 & .45 & .05 & 14.84 & .01 & .05 & .54 & .59 & .03 \\
\hline
\end{tabular}

AWWL得点が低くなった（それぞれ $p<.01 ， d=.62 ；$ $p<.01, d=.65)$.

各条件における下位項目の平均得点を図6に示した，実 験条件に関して参加者内1要因分散分析をおこなった結 果，知的知覚的要求と努力の項目において追従条件が奥 モニタ条件と手前モニタ条件よりも平均得点が低くなっ た（知的知覚的要求 : $p<.05, d=.60 ; p<.05, d=.78$; 努力: $p<.05, d=.84 ; p<.05, d=.73)$. それ以外の項 目に関しては，実験条件間の違いはみられなかった。

\section{3-3. 疲労}

フリッカー值に関して実験条件 $\times$ 課題前後の参加者 内2要因分散分析をおこなった結果，いずれの要因にお いても主効果はみられず，交互作用もみられなかった (それぞれ $F(2,34)=2.13$, n.s.,$\eta_{\mathrm{p}}{ }^{2}=.12 ; F(1,17)=$ 0.26 , n.s., $\eta_{\mathrm{p}}{ }^{2}=.02 ; F(2,34)=0.14$, n.s., $\left.\eta_{\mathrm{p}}^{2}=.01\right)$.

自覚症しらべの各群の平均得点に関して実験条件 $\times$ 課
題前後の参加者内 2 要因分散分析をおこなった．分散分 析の結果を表1に示した。分析の結果，全ての群におい て実験条件の主効果がみられなかった。 ねむけ感，不快感， だるさ感，ぼやけ感において課題前後の主効果がみられた. 実験条件と課題前後の間で交互作用はみられなかった.

\section{4. 考 察}

本研究の目的は，視覚的作業支援情報の操作対象物に 対する追従呈示が作業パフォーマンスとオペレータの疲 労や負担に及ぼす影響を明らかにすることであった。そ の結果，作業パフォーマンスと精神的負担に対して追従 呈示の効果がみられた.

作業パフォーマンスの結果（図4）より，七ットサイ ズが最大の時に追従条件で反応時間が短くなった。 セッ トサイズが大きい場合は一度に多くの立体図形がスクリー ン上に呈示される。したがって，視覚的負荷が大きい場 
合に，作業支援情報の追従の効果は大きくなるといえる． 追従呈示では，作業支援情報をスクリーン上の図形に重 ねたり，隣に配置したりすることが可能であるため，情 報確認時に生じる視覚的負荷が軽減されたと考えられる.

主観的な精神的負担の結果（図5）より，追従条件に おいてAWWL得点が低くなり，作業支援情報が追従す ることで主観的な精神的負担が軽減されることが示され た。また，下位項目の結果 (図6) より，知的知覚的要 求と努力の項目において追従条件の得点が最も低くなっ た。したがって，追従呈示することで情報を確認する時 に生じる視覚的負荷が軽減され，図形の判断を容易にお こなうことが可能となり, 課題に要する努力が少なくなっ た結果，主観的な精神的負担が軽減されたといえる.

HUD利用時には情報確認時に生じる視覚的負荷が軽減 されるため，作業パフォーマンスの向上や主観的な精神 的負担が軽減されるというメリットがある ${ }^{6 \sim 8)}$ ．その一 方で，HUDでは情報が重なって呈示されることで，現実 世界の物体の視認を妨害するというデメリットもある. 先行研究では，HUDに表示した情報が現実世界の物体と 重なる場合，物体の視認性が低下寸ることが示されてい る14,15)。しかし，追従呈示では，オペレータは現実世界 の物体と重ならない位置に作業支援情報を移動させるこ とができるため，HUD利用時に生じる重なりの影響を軽 減することができると考えられる. 本実験の追従条件では， 作業支援情報をスクリーン上の図形と重ならない位置に 移動させる方略を実験参加者が用いた可能性があったた め，作業パフォーマンスの低下や精神的負担の増大はみ られなかったと考えられる。したがって，追従呈示する ことで, HUD利用時の重なりの問題を解決する可能性が 示唆された。

一方，フリッカー值と自覚症しらべの得点に打ける分 析の結果より，いずれの指標に扔いても実験条件間での 違いはみられなかった。したがって，作業支援情報の追 従呈示によって作業者の疲労は軽減しないことが示され た。 ただし, 本研究の課題時間は15分程度であり, 実作 業に比べて短かった. フリッカーテストや自覚症しらべ は長時間の作業による疲労の変化を測定するために用い られることが多いため ${ }^{16,17)}$, 本実験のように短時間の課 題においては実験条件間での疲労の違いを示すことがで きなかったと考えられる.

\section{5. おわりに}

本研究より, 作業支援情報が操作対象物を追従するこ とで，作業をより効率的におこなうことが可能となり，
主観的な精神的負担が軽減することが示された，追従呈 示時には，情報確認時の視覚的負荷が軽減されるため， 少ない精神的負担で作業を効率的におこなうことができ たと考えられる。したがって，操作対象物に対する視覚 的作業支援情報の追従呈示は作業において有用であると 考えられる。

今後，実際にHUDを利用して作業支援情報を虚像とし て呈示した場合に，本研究と同様に追従呈示の効果が示 されるのかを検討したい。これにより，実機でのHUDに おける追従呈示の利用に近づけることができる.

\section{利益相反}

本研究は(株)コマツとの共同研究によってなされた。

\section{文 献}

1）国土交通省, “建設施工・建設機械一情報化施工”. http:// www.mlit.go.jp/sogoseisaku/constplan/sosei_constplan_ tk_000017.html, (参照2018-06-27)

2) Greenberg, J.; Tijerina, L.; et al. Evaluation of driver distraction using an event detection paradigm. Journal of the Transportation Research Board, 1984, p.1-9, doi: 10.3141/1843-01.

3) Oestlund, J.; Nilsson, L.; et al. Effect of cognitive and visual load in real and simulated driving. VTI Rapport. 2006, 533A, 88p.

4）麻生勤, 宇野宏, 他. 運転中のナビ視認時間に関する台上 試験法の検討. 自動車研究. 2002, 24 (2), p.133-136.

5）宇野宏，中村之信. 情報機器の操作が運転行動に与える 影響に関する実験研究. 自動車技術会大会論文集. 2014, 45 (2), p.387-392.

6) Stokes, A.; Wickens, C.; et al. Display Technology: Human Factors Concepts. Society of Automotive Engineers, 1990, $171 \mathrm{p}$.

7) Liu, Y. C.; Wen, M. H. Comparison of head-up displays (HUD) vs. head-down displays (HDD): driving performance of commercial vehicle operators in Taiwan. International Journal of Human-Computer Studies. 2004, $61(5)$, p.679-697.

8) Weinberg, G.; Harsham, B.; et al. "Investigating HUDs or the presentation of choice lists in car navigation systems”. Driving assessment conference: Proceedings of the sixth international driving symposium on human factors in driving assessment, training and vehicle. California, USA, 2011-06-27/30. University of lowa: Public Policy Center, p.195-202.

9) Continental Engineering Services. "Combiner Head-up Display", http://www.conti-engineering.com/CMSPages/ GetFile.aspx?guid $=8 \mathrm{fed} 7 \mathrm{f} 69-1 \mathrm{cdc}-4 \mathrm{cb} 0-8 \mathrm{aa} 5-$ a7981d1460fc, (参照2018-6-27)

10) Gabbard, J. L.; Fitch, G. M.; et al. "Behind the glass: Driver challenges and opportunities for ar automobile applications". Proceedings of the IEEE. Hong Kong, 
China, 2014-05-31/06-07, p.124-136.

11）芳賀繁. NASAタスクロードインデックス日本語版の作 成と試行. 鉄道総研報告. 1994, 8(1), p.15-20.

12）産業疲労研究会. “調査ツールー自覚症しらべ”, http:// square.umin.ac.jp/of/service.html, (参照2018-06-27)

13） 三宅晋司, 神代雅晴. メンタルワークロードの主観的評 価法一NASA-TLXとSWATの紹介および簡便法の提案一. 人間工学. 1996,26 (6), p.399-408.

14）坂元里菜, 木原健, 他. “奥行き情報が視覚的注意に与え る影響一高速逐次視覚呈示 (RSVP) 課題を用いて一”. 電 子情報通信学会HCGシンポジウム2012, 熊本, 2012-12$10 / 12$.

15）三浦弘雅, 山木善規, 他. 3次元情報表示システムにおけ る奥行き差 - 呈示時間 - 重畳配置の知覚的効果. Calsonic Kansei Technical Review. 2013, 9, p.91-98.

16) 井谷徹. 新版「自覚症しらべ」の活用法. 労働の科学. 2002, 57, p.305-308.

17）西村武, 森本一成. 精神疲労推定のためのCFFの測定方 法と条件の検討一VDT作業による疲労を対象として一. 人 間工学. 1986, 22 (4), p.203-210.

\section{著者情報}

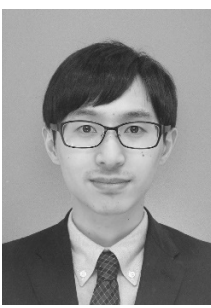

藤原悠史（ふじわらゆうし，正会員，連絡 著者）

2017 年大阪大学大学院人間科学研究科博 士前期課程修了。修士 (人間科学)。同年 より大阪大学大学院人間科学研究科博士後 期課程に在学中. 専門領域: 認知心理学, ヒューマンインタフェース。 日本人間工学 会, 日本心理学会, ヒューマンインタフェー ス学会などの会員.

連絡先 : uc.fuji@gmail.com

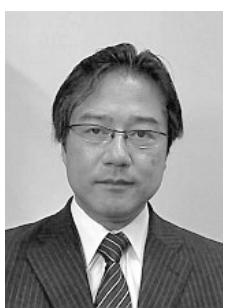

篠原一光（しのはらかずみつ，正会員） 大阪大学大学院人間科学研究科博士後期課 程中退，2001年博士 (人間科学)。1995年 大阪大学人間科学部助手，2013年より大 阪大学大学院人間科学研究科教授. 日常生 活における行動の応用認知心理学的 · 人間 工学的研究に従事. 日本人間工学会, 日本 心理学会, 日本認知心理学会などの会員.

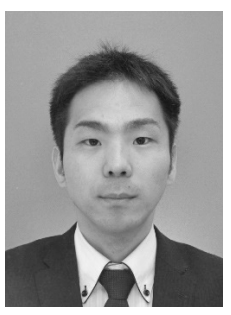

北村昭彦（きたむらあきひこ）

2017 年大阪大学大学院人間科学研究科博 士後期課程修了. 博士 (人間科学). 同年, 日本学術振興会特別研究員 (PD) を経て, 現在まで大阪大学大学院人間科学研究科助 教. 日本心理学会, ヒューマンインタフェー ス学会などの会員. 専門は認知心理学. ヒューマンインタフェース.

佐々木誠（ささきまこと）

1995年大阪大学大学院産業機械工学専攻修了後, コマツ入社. 開発本部キャブ開発センタにて運転室の設計に従事. 